\title{
Effect of Treated Waste Water Irrigation on Plant Growth and Soil Properties in Gaza Strip, Palestine
}

\author{
Yasser El-Nahhal ${ }^{1,2}$, Khalil Tubail ${ }^{1}$, Mohamad Safi ${ }^{1}$, Jamal Safi $^{1,3^{*}}$ \\ ${ }^{1}$ Environmental Protection and Research Institute, Gaza, Palestine; ${ }^{2}$ The Islamic University of Gaza, Gaza, Palestine; ${ }^{3} \mathrm{Al}-\mathrm{Azhar}$ \\ University of Gaza, Gaza, Palestine. \\ Email: "eprigaza@palnet.com
}

Received June $30^{\text {th }}, 2013$; revised July $30^{\text {th }}, 2013$; accepted August $10^{\text {th }}, 2013$

Copyright (C) 2013 Yasser El-Nahhal et al. This is an open access article distributed under the Creative Commons Attribution License, which permits unrestricted use, distribution, and reproduction in any medium, provided the original work is properly cited.

\begin{abstract}
This study investigated the effect of treated wastewater (TWW) irrigation on growth of Chinese cabbage and corn and on soil properties in Gaza Strip, Palestine. Chinese cabbage and corn were planted in winter and summer seasons respectively in a sandy soil. The experimental design was a randomized complete block using 2 treatments with 4 replicates. Soil samples were collected from 0.0 - $120 \mathrm{~cm}$ depths from all plots and analyzed for $\mathrm{pH}$, electric conductivity (EC) and nutrient contents. The plants were irrigated with either TWW or fresh water (FW) fortified with NPK, while control used drip irrigation system. The biomass (total fresh weight of the plants) was used as an indicator of the plant yields. Concentration of heavy metals on plant leaves was determined by Inductive Coupled Plasma Analyzer (ICP) and was taken as an indicator of plant quality. Biomass of Chinese cabbage and corn grown in plots irrigated with TWW was higher than those grown in plots irrigated with FW. These results indicate the ability of TWW supplying the necessary nutrients for plant growth. Heavy metal content in plant leaves in all treatments (TWW and FW) was nearly similar and below EPA standards, indicating high quality of plants. Soil analysis showed great changes in soil properties due to irrigation with TWW. The interesting outcome of this study is that TWW is an effective source for plant nutrients. It is encouraging to reuse TWW in agricultural system after full treatment.
\end{abstract}

Keywords: TWW; FW; Corn; Chinese Cabbage; Heavy Metals

\section{Introduction}

The quantity of treated wastewater (TWW) in Gaza is about $111,900 \mathrm{~m}^{3} /$ day [1]. This quantity is expected to increase during the coming years due to population growth. Guidelines for safe and effective reuse of TWW for agricultural purposes are not yet approved by the Palestinian Authority, or any Research Institute. Regardless of this fact, this high quantity of TWW should be reused in the agricultural or industrial sectors to solve the problem of water quality in Gaza Strip Palestine. Although TWW in Gaza did not meet the international standards, several trials have been made by international institutions in Gaza for the reuse of TWW in agriculture. For instance, effluent from the existing Gaza waste water treatment plants (WWTP) is currently being used by farmers through pilot projects funded by the Spanish and French governments. In the Spanish project the trial includes irrigation of citrus and olive trees in Gaza area

*Corresponding author.
(Stawi Farm in Al Zeitoon area, 100 dunums), and in the French project the trial includes irrigation of forage crops in North area ( beit Lahia, 40 dunums). Obviously, these trials are not based on scientific research. They used the TWW without looking into the quality of the products or the effect of TWW in soil properties.

Nevertheless, elsewhere several investigations have been made to evaluate the quality of TWW for possible reuse in agricultural sectors. For instance, Evett et al. [2] evaluated the feasibility of using TWW irrigation strategies based on 1) water use of different tree species, 2) weather conditions in different climate zones of Egypt, 3) soil types and available irrigation systems, and 4) the requirement to avoid deep percolation losses that could lead to groundwater contamination. They concluded that drip irrigation systems are preferred to achieve several small irrigations per day in order to avoid deep percolation losses. Mendoza-Espinosa et al. [3] evaluated the effect of treated wastewater on the growth of cabernet sauvignon and merlot grapes from the Guadalupe Valley, 
Mexico. They reported that the number of leaves per shoot and the overall biomass increased in plants irrigated with wastewater and grape production per plant was $20 \%$ higher and the concentration of carbohydrates, organic acids and $\mathrm{pH}$ were similar in grapes from vines irrigated with wastewater to those irrigated with groundwater. Oron et al. [4] evaluated the influence of TWW on sustainable agricultural production and safe groundwater recharge using filed experiment. They reported that ultrafiltration stage is efficient in the removal of the pathogens and suspended organic matter while the successive Reverse Osmosis (RO) stage provides safe removal of the dissolved solids (salinity). Best agricultural yields were obtained when applying effluent had minimal content of dissolved solids (after the RO stage) as compared with secondary effluent without any further treatment and extended storage. Mosse et al. [5] investigated the effect of application of winery wastewaters to physicochemical properties of soils. They concluded that longterm application of winery wastewaters had significant impacts on soil respiration, nitrogen cycling and microbial community structure, but the treated wastewater application showed no significant differences in wetting alone. Singh et al. [6] investigated the effect of land application of sewage sludge on the physicochemical properties of soils. They concluded that amending soil with sewage sludge modified the physicochemical properties of soils, and might contaminate ground water, stock ponds, or produce food chain contamination from eating food grown in sludge-treated land. Castro et al. [7] studied the effects of wastewater irrigation on turfgrass growth, and reported that plants irrigated with treated wastewater had the highest sodium content. Pritchard et al. [8] investigated the risks of the environment and food crops that may come from land application of sewage sludge in Australia. They reported that the attention was given to researches related to plant nutrient uptake, particularly nitrogen and phosphorus (including reduced phosphorus uptake in alum sludge-amended soil); the risk of heavy metal uptake by plants, specifically cadmium, copper and zinc; the risk of pathogen contamination in soil and grain products; change of soil $\mathrm{pH}$. Belyaeva et al. [9] investigated the effects of adding biosolids to a green waste feedstock ( $100 \%$ green waste, $25 \%$ $\mathrm{v} / \mathrm{v}$ biosolids or $50 \%$ biosolids) on the properties of composted products. They found that addition of biosolids to the feedstock increased total $\mathrm{N}, \mathrm{EC}$, extractable $\mathrm{NH}(4)$, $\mathrm{NO}(3)$ and $\mathrm{P}$ but lowered $\mathrm{pH}$, macroporosity, water holding capacity, microbial biomass $\mathrm{C}$ and basal respiration in composts. This paper investigates the effect of TWW irrigation on Chinese cabbage and corn growth and quality and on soil properties in Gaza Soil.

\section{Materials and Methods}

\subsection{Environmental Background of the Study Area}

Gaza Strip is a semi-arid region of roughly $365 \mathrm{~km}^{2}$ which lies on the Mediterranean Sea. On this narrow strip, almost 1.625 million of the Palestinian people live and work [10]. The ground water is used for irrigation, industrial and domestic purposes. A "Catastrophic" water shortage, water pollution with high salinity and micropollutants, lack of sewage and solid waste treatment, maritime pollution, overcrowding, poverty and uncontrolled use of pesticides are the most pressing environmental problems in the Gaza Strip. Internationally suspended, banned and canceled pesticides which considered mutagenic and carcinogenic are still used in the agricultural environment. The wastewater sector in the Gaza Strip is characterized by poor sanitation, insufficient treatment and unsafe disposal. Currently, there are four wastewater treatment plants in operation in the Gaza Strip namely: Beit Lahia, Gaza, Khan Younis and Rafah Wastewater Treatment Plants (WWTP's) receiving about 24 Million $\mathrm{m}^{3}$ of raw sewage per year.

\subsection{Experimental Design}

The experimental site was selected as sandy soil in the north zone of the Gaza Strip. Two treatments were selected: one irrigated with TWW and the other with fresh water ( FW). Each treatment contains 4 replicates (plots). Plot dimensions are $5 \times 4 \mathrm{~m}$. Each plot is divided into 5 rows for planting (12 plants in each row). The experimental design was established as a randomized complete block design. Chinese cabbage seedlings were planted for first season on 28/11/2010 and harvested on 9/3/2011 and for the 2nd season on 11/11/2011 and harvested on $21 / 2 / 2012$. Corn seeds were sown for the 1 st season on $21 / 3 / 2011$ and harvested on 25/6/2011 and for 2nd season $21 / 3 / 2012$ and harvested on 25/6/2012.

\subsection{Soil Analysis}

Soil samples from depths of $0.0-30,30-60,60$ - 90 and $90-120 \mathrm{~cm}$ depth were collected from eight soil profiles dug in all plots. The soil samples were air dried, sieved through $2 \mathrm{~mm}$ mesh and kept in plastic bags in the laboratory for $\mathrm{pH}, \mathrm{EC}$ and nutrient contents using the standard methods.

\subsection{Irrigation Water and Analysis}

Treated wastewater (TWW) from Beit Lahia wastewater treatment plant and fresh water (FW) from local well were used for irrigation. The irrigated plants are Chinese cabbage as winter crop and corn (Zea maiz, Variety 
Merit) as summer crop was grown on a sandy soil. Irrigation was managed by a drip irrigation system with discharge of $4 \mathrm{~L} / \mathrm{plant} / \mathrm{h}$ according to the standard water requirements [11].

Samples of TWW and FW were analyzed for physicochemical properties following the procedure described in the standard method [12].

\subsection{Harvesting, Plant Sampling and Preparation}

Plants were harvested after four months of planting day or by the end of each season. The biomass of Chinese cabbage and corn were collected and weighed and used as growth indicator.

Chinese cabbage and corn leaves were sampled randomly from several plants of each plot on the harvesting day at the end of winter season, whereas, corn leaves were sampled at the end of summer season. Leave samples were collected from several plants of each plot. The samples were washed with tap water to remove atmospheric dust sand and then washed with distilled water. Leave samples were then oven dried at $65^{\circ} \mathrm{C}$ for 48 hours, ground and kept in well sealed plastic bags and stored at room temperature for elemental analysis.

\subsection{Elemental Analysis}

About $0.5 \mathrm{~g}$ of oven dried leave sample as mentioned above was digested with concentrated nitric acid in glass tube at $80^{\circ} \mathrm{C}$ for $48-72 \mathrm{~h}$ then heated up to $120^{\circ} \mathrm{C}$ for 4 $8 \mathrm{~h}$ to have clear solution as previously described [13]. Samples then were cooled and diluted with distilled water up to $25 \mathrm{ml}$, filtered using small glass or plastic funnels pre-washed with sulfuric acid. Elements concentration in the filtrate was determined using ICP. Two determinations were conducted per replicate

\subsection{Data Analysis}

The data were statistically analyzed using mean and standard deviations. Analysis of variance between treatments was conducted using T-Test. P-values associated with T-test were taken as an indicator of significant differences among the treatments. P-values are presented below Tables. P-values less than 0.05 are considered significant.

\section{Results and Discussion}

\subsection{Soil Analysis}

Soil components and soil texture of the field plots are shown in Table 1. It can be seen the clay fraction of soil ranged between $2 \%$ - 5\% in different depths of the soil profiles. Accordingly soil can be classified as sandy soil.
Furthermore, the sand fraction of soils in all depths ranged between $91 \%$ - 94\% indicating sand texture of soil.

Biological, physical and chemical properties of irrigation water are shown in Tables 2.

BOD, COD, TSS, and EC stand for: biological oxygen demand, chemical oxygen demand, total suspended solids and electric conductivity, respectively.

It can be seen that BOD, COD and TSS are nil in FW whereas high values are observed in TWW. In addition, nitrate level in FW is higher than in TWW. The explanation of these results is that $\mathrm{FW}$ is nitrogen phosphorus

Table 1. Soil fractions and texture.

\begin{tabular}{ccccc}
\hline Depth $(\mathrm{cm})$ & Sand \% & Silt \% & Clay \% & Soil Texture \\
\hline $0-30$ & 94 & 4 & 2 & Sandy \\
$30-60$ & 92 & 5 & 3 & Sandy \\
$60-90$ & 91 & 4 & 5 & Sandy \\
$90-120$ & 92 & 4 & 4 & Sandy \\
\hline
\end{tabular}

Table 2. biological and chemical properties of irrigation water, 2011.

\begin{tabular}{|c|c|c|}
\hline Properties & FW & TWW \\
\hline $\mathrm{BOD}(\mathrm{mg} / \mathrm{L})$ & - & 95.8 \\
\hline $\mathrm{COD}(\mathrm{mg} / \mathrm{L})$ & - & 242.3 \\
\hline TSS (mg/L) & - & 108.7 \\
\hline $\mathrm{pH}$ & 8.22 & 8.41 \\
\hline $\mathrm{EC}(\mathrm{dsim} / \mathrm{m})$ & 2.39 & 2.2 \\
\hline $\mathrm{N}-\mathrm{NO}_{3}(\mathrm{mg} / \mathrm{L})$ & 38.9 & 1.6 \\
\hline $\mathrm{N}-\mathrm{NH}_{4}(\mathrm{mg} / \mathrm{L})$ & - & 51.6 \\
\hline $\mathrm{K} \mathrm{mg/l}$ & 3.8 & 21.7 \\
\hline $\mathrm{Na}(\mathrm{mg} / \mathrm{L})$ & 115 & 159 \\
\hline $\mathrm{Ca} \mathrm{mg} / \mathrm{L}$ & 215 & 112 \\
\hline $\mathrm{Mg}$ & 36 & 41 \\
\hline SAR & 1.9 & 3.3 \\
\hline $\mathrm{S} \mathrm{mg} / \mathrm{L}$ & 34 & 20 \\
\hline $\mathrm{P} \mathrm{mg} / \mathrm{L}$ & 0.07 & 4.89 \\
\hline B (ppm) & 0.07 & 0.17 \\
\hline $\mathrm{Cl}$ (ppm) & 505 & 351 \\
\hline $\mathrm{Cr}$ (ppm) & 0.005 & 0.001 \\
\hline $\mathrm{Cu}(\mathrm{ppm})$ & 0.002 & 0.003 \\
\hline $\mathrm{Fe}(\mathrm{ppm})$ & 0.002 & 0.009 \\
\hline Mn (ppm) & 0.001 & 0.002 \\
\hline $\mathrm{Ni}(\mathrm{ppm})$ & 0.016 & 0.018 \\
\hline
\end{tabular}


potassium (NPK) fortified whereas in TWW the nitrate level is being reduced to ammonium hydroxide due to an aerobic condition. Accordingly low level of nitrate is available in TWW. Sodium and Potassium are several times higher in TWW than in FW. Calcium concentration is higher in FW than in TWW whereas Magnesium has opposite direction. Sulfur concentration is higher in FW than TWW due to possible transformation of sulfate to hydrogen sulfide in TWW due to an aerobic conditions. Phosphorus and Barium are higher in TWW than in FW. Chloride is higher in FW than in TWW due to chlorinetion process in drinking water. Heavy metal contents ranged from 0.001 to $0.018 \mathrm{ppm}$ in $\mathrm{FW}$ and TWW indicating low contents. Comparison with EPA standards shows that the properties of the used water are within the range. Accordingly, the current water situation may be used for agricultural irrigation. The following: $\mathrm{Ag}, \mathrm{As}, \mathrm{Bi}$, $\mathrm{Cd}, \mathrm{Co}, \mathrm{Hg}, \mathrm{Mo}, \mathrm{Pb}, \mathrm{Se}$ and $\mathrm{Sn}$ were not detected in the used water.

Table 3 shows $\mathrm{pH}$ and EC values for the soil profiles. It is obvious that $\mathrm{pH}$ values ranged between $7.69 \pm 0.21$ to $8.05 \pm 0.15$ in FW and from $7.75 \pm 0.1$ to $8.1 \pm 0.01$ in TWW plots.

It is obvious that soil is more acidic at the top layers $0.0-30 \mathrm{~cm}$ depth and less acidic at deeper depths in FW and TWW plots. EC values are high in the top soil layers (Table 3) and several times lower in deeper depths (90 $120 \mathrm{~cm}$ ) in both FW and TWW plots. This may be due to accumulation of less soluble salts in the tope soil layer and possible formation of organic acids due to biodegradation of organic compounds in soils. These results are in accord with Belyaeva et al. [9] who found lower $\mathrm{pH}$ in the top soil due to addition of biosolids.

Statistical analysis for comparison between $\mathrm{pH}$, and EC values in soil profiles of 2011 does not show significant differences in $\mathrm{pH}$ and $\mathrm{EC}$ values in TWW and FW. $\mathrm{P}$-values are 0.18 and 0.43 respectively.

Our results agree with Castro et al. [7] who investigated the effects of wastewater irrigation on soil properties and turfgrass growth and concluded that there were no negative effects with respect to changes in soil $\mathrm{pH}$ but a significant increase in electrical conductivity and sodium content was observed in wastewater-irrigated soil.

Table 3. pH, and EC (dS/m) of soil profile, 2011.

\begin{tabular}{ccccc}
\hline \multirow{2}{*}{ Depth $(\mathrm{cm})$} & \multicolumn{2}{c}{ FW } & \multicolumn{2}{c}{ TWW } \\
\cline { 2 - 5 } & $\mathrm{pH}$ & $\mathrm{EC}(\mathrm{dS} / \mathrm{m})$ & $\mathrm{pH}$ & $\mathrm{EC}(\mathrm{dS} / \mathrm{m})$ \\
\hline $0-30$ & $7.69 \pm 0.21$ & $0.57 \pm 0.25$ & $7.73 \pm 0.1$ & $0.52 \pm 0.21$ \\
$30-60$ & $7.88 \pm 0.21$ & $0.27 \pm 0.06$ & $8.08 \pm 0.14$ & $0.27 \pm 0.07$ \\
$60-90$ & $7.89 \pm 0.12$ & $0.18(0.02)$ & $8.05 \pm 0.16$ & $0.15 \pm 0.02$ \\
$90-120$ & $8.05 \pm 0.15$ & $0.15 \pm 0.01$ & $8.10 \pm 0.14$ & $0.14 \pm 0.02$ \\
\hline
\end{tabular}

Nitrate concentrations (Table 4) decreased from the top 0 - 30 to deeper depths in both treatments (TWW and FW). Nitrate concentration of the soil 0 - 30 of FW-profile is lower than TWW-profile as well as higher than other depths.

Chloride concentrations of soil profile are higher in the FW-samples than in the TWW-treated samples. Statistical analysis for comparison between $\mathrm{N}-\mathrm{NO}_{3}$, and $\mathrm{Cl}^{-}$values in soil profiles of 2011 does not show significant differences in $\mathrm{N}_{-} \mathrm{NO}_{3}$, and $\mathrm{Cl}^{-}$values in TWW and FW. Pvalues are 0.2 and 0.34 respectively. Our results agree with Boruah and Hazarika [14] who concluded that available N, K, S and exchangeable and water soluble $\mathrm{Na}, \mathrm{K}$, $\mathrm{Ca}, \mathrm{Mg}$ were highest in effluent irrigated soil.

Regardless to the highest values of organic matter that found at depth $30-60 \mathrm{~cm}$ (Table 5), the mount of organic carbon decreased from the top to deeper depths in both treatments (FW and TWW). Statistical analysis shows no differences between treatments, P-value equals to 0.45 .

Our results agree with Adrover et al. [15] who investigated the chemical properties and biological activity in soils of Mallorca following twenty years of treated wastewater irrigation and did not observe negative effects on cation exchange capacity, $\mathrm{pH}$, calcium carbonate equivalent, and soil organic matter.

Macronutrients, micronutrients and heavy metal concentrations in soil profiles are presented in Tables 6-8.

It can be seen that the concentrations of $\mathrm{P}$ (Table 6) are ranged between $0.19-0.58 \mathrm{ppm}$ in all depths of FW and TWW treatments. This low value is due to low solubility of $\mathrm{P}$ in soil solution due to high soil pH (Table 3). These results agree with Metson et al. [16] who found

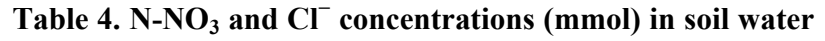
extract (1:1).

\begin{tabular}{ccccc}
\hline \multirow{2}{*}{ Depth $(\mathrm{cm})$} & \multicolumn{2}{c}{$\mathrm{FW}$} & \multicolumn{2}{c}{$\mathrm{TWW}$} \\
\cline { 2 - 5 } & $\mathrm{N}^{-\mathrm{NO}_{3}}$ & $\mathrm{Cl}^{-}$ & $\mathrm{N}-\mathrm{NO}_{3}$ & $\mathrm{Cl}^{-}$ \\
\hline $0-30$ & $0.76 \pm 0.22$ & $3.0 \pm 1.78$ & $1.01 \pm 0.43$ & $2.8 \pm 1.35$ \\
$30-60$ & $0.46 \pm 0.26$ & $1.09 \pm 0.56$ & $0.64 \pm 0.38$ & $1.1 \pm 0.44$ \\
$60-90$ & $0.41 \pm 0.05$ & $0.62 \pm 0.26$ & $0.49 \pm 0.15$ & $0.34 \pm 0.21$ \\
$90-120$ & $0.32 \pm 0.02$ & $0.43^{\prime} \pm 0.35$ & $0.41 \pm 0.23$ & $0.39 \pm 0.11$ \\
\hline
\end{tabular}

Table 5. Total organic carbon (ppm) of soil profile, 2011.

\begin{tabular}{ccc}
\hline Depth $(\mathrm{cm})$ & FW & TWW \\
\hline $0-30$ & $26.2 \pm 2.75$ & $27.7 \pm 10.9$ \\
$30-60$ & $32.1 \pm 23.7$ & $27.5 \pm 13.6$ \\
$60-90$ & $15.6 \pm 3.48$ & $14.76 \pm 4.33$ \\
$90-120$ & $12.0 \pm 1.23$ & $12.61 \pm 2.95$ \\
\hline
\end{tabular}


Table 6. Macronutrients concentration (ppm) in soil profile, 2011.

\begin{tabular}{ccccccccc}
\hline \multirow{2}{*}{ Element } & \multicolumn{3}{c}{ FW } & \multicolumn{3}{c}{ TWW } \\
\cline { 2 - 8 } & $0-30$ & $30-60$ & $60-90$ & $90-120$ & $0-30$ & $30-60$ & $60-90$ & $90-120$ \\
\hline $\mathrm{P}$ & $0.22 \pm 0.1$ & $0.24 \pm 0.1$ & $0.43 \pm 0.3$ & $0.19 \pm 0.06$ & $0.17 \pm 0.06$ & $0.21 \pm 0.07$ & $0.58 \pm 0.32$ & $0.57 \pm 0.46$ \\
$\mathrm{~K}$ & $6.5 \pm 2.2$ & $1.70 \pm 0.6$ & $1.80 \pm 0.4$ & $2.50 \pm 1.2$ & $5.9 \pm 3.30$ & $2.2 \pm 0.70$ & $2.2 \pm 0.40$ & $2.5 \pm 1.0$ \\
$\mathrm{Ca}$ & $60.7 \pm 4.13$ & $29.2 \pm 7.0$ & $19.5 \pm 2.20$ & $18.5 \pm 2.70$ & $48.5 \pm 15.6$ & $32.7 \pm 4.10$ & $20.1 \pm 6.6$ & $25.7 \pm 11.0$ \\
$\mathrm{Mg}$ & $9.25 \pm 4.13$ & $3.95 \pm 0.88$ & $2.58 \pm 0.19$ & $2.18 \pm 0.25$ & $3.24 \pm 0.33$ & $3.55 \pm 1.66$ & $2.81 \pm 0.50$ & $2.71 \pm 0.63$ \\
$\mathrm{~S}$ & $13.4 \pm 6.90$ & $5.60 \pm 1.10$ & $4.10 \pm 1.10$ & $3.30 \pm 0.60$ & $2.19 \pm 0.27$ & $2.57 \pm 2.82$ & $1.15 \pm 0.42$ & $1.0 \pm 0.57$ \\
$\mathrm{Na}$ & $41.1 \pm 20.8$ & $20.8 \pm 3.80$ & $13.2 \pm 2.30$ & $13.5 \pm 4.70$ & $2.53 \pm 1.07$ & $1.38 \pm 0.64$ & $1.07 \pm 0.30$ & $1.1 \pm 0.21$ \\
\hline
\end{tabular}

Table 7. Micronutrients concentration (ppm) in soil profile, 2011.

\begin{tabular}{ccccccccc}
\hline \multirow{2}{*}{ Element } & \multicolumn{3}{c}{ FW } & \multicolumn{3}{c}{ TWW } \\
\cline { 2 - 9 } & $0-30$ & $30-60$ & $60-90$ & $90-120$ & $0-30$ & $30-60$ & $60-90$ & $90-120$ \\
\hline $\mathrm{Fe}$ & $0.104 \pm 0.11$ & $0.320 \pm 0.32$ & $0.622 \pm 0.33$ & $0.833 \pm 0.37$ & $0.05 \pm 0.02$ & $0.35 \pm 0.28$ & $1.44 \pm 0.58$ & $1.69 \pm 1.19$ \\
$\mathrm{Zn}$ & $0.031 \pm 0.01$ & $0.037 \pm 0.02$ & $0.034 \pm 0.02$ & $0.022 \pm 0.01$ & $0.023 \pm 0.01$ & $0.026 \pm 0.01$ & $0.032 \pm 0.02$ & $0.028 \pm 0.01$ \\
$\mathrm{Mn}$ & $0.020 \pm 0.02$ & $0.07 \pm 0.09$ & $0.03 \pm 0.02$ & $0.05 \pm 0.02$ & $0.01 \pm 0,01$ & $0.04 \pm 0.02$ & $0.14 \pm 0.03$ & $0.10 \pm 0.08$ \\
$\mathrm{Cu}$ & $0.011 \pm 0.00$ & $0.01 \pm 0.00$ & $0.01 \pm 0.00$ & $0.01 \pm 0.00$ & $0.011 \pm 0.00$ & $0.01 \pm 0.00$ & $0.01 \pm 0.00$ & $0.01 \pm 0.00$ \\
$\mathrm{~B}$ & $0.04 \pm 0.01$ & $0.04 \pm 0.02$ & $0.03 \pm 0.00$ & $0.03 \pm 0.01$ & $0.05 \pm 0.01$ & $0.041 \pm 0.02$ & $0.03 \pm 0.01$ & $0.03 \pm 0.01$ \\
\hline
\end{tabular}

Table 8. Heavy metals concentration (ppm) in soil profile, 2011.

\begin{tabular}{ccccccccc}
\hline \multirow{2}{*}{ Element } & \multicolumn{3}{c}{ FW } & \multicolumn{3}{c}{ TWW } \\
\cline { 2 - 9 } & $0-30$ & $30-60$ & $60-90$ & $90-120$ & $0-30$ & $30-60$ & $60-90$ & $90-120$ \\
\hline $\mathrm{Co}$ & $0.002 \pm 0.00$ & $0.000 \pm 0.00$ & $0.000 \pm 0.00$ & $0.000 \pm 0.00$ & $0.002 \pm 0.00$ & $0.001 \pm 0.00$ & $0.001 \pm 0.00$ & $0.001 \pm 0.00$ \\
$\mathrm{Cr}$ & $0.001 \pm 0.00$ & $0.002 \pm 0.00$ & $0.003 \pm 0.00$ & $0.004 \pm 0.00$ & $0.002 \pm 0.00$ & $0.005 \pm 0.00$ & $0.004 \pm 0.00$ & $0.007 \pm 0.00$ \\
$\mathrm{Ni}$ & $0.013 \pm 0.00$ & $0.011 \pm 0.00$ & $0.013 \pm 0.00$ & $0.012 \pm 0.00$ & $0.011 \pm 0.00$ & $0.012 \pm 0.00$ & $0.017 \pm 0.00$ & $0.017 \pm 0.00$ \\
$\mathrm{~Pb}$ & $0.109 \pm 0.11$ & $0.333 \pm 0.33$ & $0.648 \pm 0.34$ & $0.879 \pm 0.37$ & $0.047 \pm 0.02$ & $0.36 \pm 0.28$ & $1.54 \pm 0.62$ & $1.77 \pm 1.26$ \\
$\mathrm{Al}$ & $0.123 \pm 0.13$ & $0.398 \pm 0.39$ & $0.823 \pm 0.43$ & $1.161 \pm 0.47$ & $0.053 \pm 0.03$ & $0.47 \pm 0.39$ & $2.120 \pm 0.80$ & $2.378 \pm 1.54$ \\
\hline
\end{tabular}

similar results of $\mathrm{P}$ in an urban ecosystem. Concentrations of $\mathrm{K}, \mathrm{Ca}, \mathrm{Mg}, \mathrm{S}$ and $\mathrm{Na}$ are higher in the top soil layers than deeper depths in both treatments. Concentration of micronutrients in soil profile are shown in Table 7. It can be seen that except Fe, concentrations of $\mathrm{Zn}, \mathrm{Mn}$, $\mathrm{Cu}$, and $\mathrm{B}$ are below $0.15 \mathrm{ppm}$ indicating poor nutrient conditions. Furthermore, it can be seen that concentration of $\mathrm{Fe}$ is increased from top soil layer to deeper depths, indicating leaching of iron in Gaza Soils. However, the poor concentration of micronutrients in soil is in agreement with the general concept of sandy soils.

Concentrations of heavy metals are shown in Table 8. It is obvious that concentrations of $\mathrm{Co}, \mathrm{Cr}$, and $\mathrm{Ni}$ are below $0.02 \mathrm{ppm}$ in both treatment (FW and TWW). These values indicate low contents of heavy metals in soil.
Similar results were recently observed [17], who made a geochemical survey in Italy and revealed the presence of huge volumes of composite wastes which accumulated up to a thickness of $25.6 \mathrm{~m}$.

Furthermore, levels of $\mathrm{Pb}$ and $\mathrm{Al}$ are increasing gradually as increasing soil depth in both treatment (FW and TWW) indicating leaching of these metals in Gaza soils.

An interesting conclusion of these results is that $\mathrm{Fe}, \mathrm{Pb}$ and $\mathrm{Al}$ pose threat to groundwater in Gaza.

\subsection{Effect of TWW on Biomass}

The total biomass of Chinese cabbage and corn are presented in Tables 9. Generally, it is obvious that there is an increase in both plant growth from year 2011 to year 2012. Furthermore, the fresh weight of Chinese cabbage 
in plots irrigated with TWW is higher than those irrigated with FW in year 2011 and 2012.

Statistical analysis showed a significant difference between the average bio-mass of the two treatments (TWW and FW). P-value equals to 0.015 . Moreover, similar trend is observed for corn plants (Table 9) indicating high yields.

Statistical analysis showed significant differences between FW and TWW treatments. This suggests that TWW can supply enough nutrients the same as the NPK fortified FW treatment equivalent to the nutrient contents of treated wastewater. This suggestion is supported by the data in Table 2 (water analysis). In addition, our results agree with resent reports [7,18-20] who analyzed the long term effects of two gradients: spatial (relative distance from the water channel) and land use intensity (cropping frequency) and addition of organic amendment on soil properties and model crop (barley) response. They demonstrated the clear and consistent patterns in soil properties and plant response along the gradients and points out the probable long-term environmental trends in a "would be" scenario for agricultural use of similar polluted soils.

Comparison between the biomass 2011 and 2012 shows a great increase in the biomass in year 2012. The explanation of these results is that application of TWW may enrich the soil with necessary nutrients that enabled plant growth. Beside the fact that TWW contains some bacteria as shown from the high BOD value (Table 2) that participate in the degradation or organic matter that maintain soil fertility. This explanation is supported by Mousavi et al. [21] who showed that irrigation with TWW had a significant positive impact on all characters of quality of maize.

\subsection{Determination of Micronutrients and Heavy Metals in Plant Leaves}

Levels of micronutrients and heavy metals in Chinese cabbage leaves are shown in Tables $\mathbf{1 0}$ and $\mathbf{1 1}$ respectively. The levels of micronutrients in Chinese cabbage leaves in 2010-2011 (Table 10) indicate that Fe levels are high in Chinese cabbage leaves in both treatments. Its concentration did not exceed $192.35 \pm 62.81$ in both FW

Table 9. Average weight of Chinese cabbage and corn (Kg/plot).

\begin{tabular}{ccccc}
\hline \multirow{2}{*}{ Treatment } & \multicolumn{2}{c}{ Chinese cabbage } & \multicolumn{2}{c}{ Corn } \\
\cline { 2 - 5 } & 2011 & 2012 & 2011 & 2012 \\
\hline FW & $33.9 \pm 2.8$ & $42 \pm 9.1$ & $32.9 \pm 3.93$ & $55.17 \pm 12.9$ \\
TWW & $38.6 \pm 3.1$ & $47 \pm 10.4$ & $46.73 \pm 6.6$ & $52.93 \pm 10.73$ \\
\hline
\end{tabular}

Fresh Weight \pm SD, $P$ value between 2011 treatments $=0.015$ for Chinese cabbage; P value between 2011 treatments $=0.04$.
Table 10. Micronutrients level $(\mathrm{mg} / \mathrm{kg})$ in Chinese cabbage leaves 2010-2011.

\begin{tabular}{ccccc}
\hline \multirow{2}{*}{ Element } & \multicolumn{2}{c}{ FW } & \multicolumn{2}{c}{ TWW } \\
\cline { 2 - 5 } & 2010 & 2011 & 2010 & 2011 \\
\hline $\mathrm{Fe}$ & $164.3 \pm 33.9$ & $192.35 \pm 62.81$ & $166.2 \pm 25.78$ & $148.27 \pm 22.89$ \\
$\mathrm{Cu}$ & $3.54 \pm 0.49$ & $3.79 \pm 0.86$ & $3.28 \pm 0.63$ & $4.38 \pm 0.62$ \\
$\mathrm{Zn}$ & $30.7 \pm 5.3$ & $38.16 \pm 0.81$ & $27.99 \pm 2.65$ & $38.33 \pm 7.15$ \\
$\mathrm{Mn}$ & $32.53 \pm 6.44$ & $42.37 \pm 8.17$ & $36.57 \pm 8.02$ & $35.15 \pm 4.17$ \\
$\mathrm{~B}$ & nd & $26.5 \pm 5.4$ & nd & $30.61 \pm 7.05$ \\
\hline
\end{tabular}

Table 11. Heavy metals level in Chinese cabbage leaves (Mean \pm SD).

\begin{tabular}{ccccc}
\hline \multirow{2}{*}{ Element } & \multicolumn{2}{c}{ FW } & \multicolumn{2}{c}{ TWW } \\
\cline { 2 - 5 } & 2010 & 2011 & 2010 & 2011 \\
\hline $\mathrm{Cr}$ & $0.673 \pm 0.12$ & $0.55 \pm 0.25$ & $0.58 \pm 0.1$ & $0.54 \pm 0.16$ \\
$\mathrm{Ni}$ & $1.42 \pm 0.49$ & $0.77 \pm 0.24$ & $1.06 \pm 0.34$ & $0.81 \pm 0.21$ \\
$\mathrm{Sn}$ & $0.58 \pm 0.33$ & $4.34 \pm 1.47$ & $0.82 \pm 0.33$ & $6.87 \pm 3.95$ \\
$\mathrm{Cd}$ & $0.08 \pm 0.01$ & $0.12 \pm 0.08$ & $0.07 \pm 0.01$ & $0.06 \pm 0.00$ \\
$\mathrm{Co}$ & nd & $0.18 \pm 0.10$ & nd & $0.14 \pm 0.02$ \\
\hline
\end{tabular}

and TWW treatments.

Concentrations of $\mathrm{Cu}$ did not exceed $4.38 \pm 0.62$ $\mathrm{mg} / \mathrm{kg}$ in both treatments (FW and TWW) during the 2 growing seasons. Concentrations of $\mathrm{Zn}$ reached $38.33 \pm$ $7.15 \mathrm{mg} / \mathrm{kg}$ indicating elevated levels. Concentrations of $\mathrm{Mn}$ are nearly similar in both TWW and FW but in year 2011 the levels reached to $42.37 \pm 8.17 \mathrm{mg} / \mathrm{kg}$ indicating high concentrations. Concentration levels of $\mathrm{B}$ are high in year 2011 and not detected in year 2010 in both treatments. Concentrations of heavy metals in Chinese cabbage leaves are shown in Table 11. It can be seen that concentrations of $\mathrm{Cr}, \mathrm{Ni}, \mathrm{Sn}$ and $\mathrm{Cd}$ did not exceed 2 $\mathrm{mg} / \mathrm{kg}$ in year 2010 whereas only Sn exceeded $2 \mathrm{mg} / \mathrm{kg}$ in year 2011 and reached 4.34 and $6.87 \mathrm{mg} / \mathrm{kg}$ in FW and TWW respectively. These elevated levels indicating high contamination levels. These results agree with Ferrara et al. [17] who revealed that levels of $\mathrm{As}, \mathrm{Cd}, \mathrm{Cr}, \mathrm{Cu}, \mathrm{Hg}$, $\mathrm{Pb}, \mathrm{Sn}, \mathrm{Tl}$ and $\mathrm{Zn}$ exceeding the intervention legal limits when irrigated with TWW.

Levels of micronutrients and heavy metals in corn leaves are shown in Tables $\mathbf{1 2}$ and $\mathbf{1 3}$ respectively.

Concentrations of some micronutrients in corn leaves are shown in Table 12.

It can be seen that concentrations of $\mathrm{Fe}$ ranged between $79.4 \pm 11.19$ to $128.41 \pm 16.00 \mathrm{mg} / \mathrm{kg}$ indicating wide variations. Concentrations of $\mathrm{Cu}$ ranged between $6.18 \pm 0.83$ to $7.63 \pm 1.22 \mathrm{mg} / \mathrm{kg}$ indication similarity in both treatments in the 2 growing season. 
Table 12. Micronutrients level $(\mathrm{mg} / \mathrm{kg})$ in corn leaves 20102011 (Mean \pm SD).

\begin{tabular}{ccccc}
\hline \multirow{2}{*}{ Element } & \multicolumn{2}{c}{ FW } & \multicolumn{2}{c}{ TWW } \\
\cline { 2 - 5 } & 2010 & 2011 & 2010 & 2011 \\
\hline $\mathrm{Fe}$ & $104.6 \pm 30.86$ & $128.41 \pm 16.00$ & $79.4 \pm 11.19$ & $124.8 \pm 23.4$ \\
$\mathrm{Cu}$ & $7.63 \pm 1.22$ & $6.18 \pm 0.83$ & $6.23 \pm 1.34$ & $6.21 \pm 1.43$ \\
$\mathrm{Zn}$ & $83.48 \pm 32.05$ & $63.09 \pm 12.24$ & $57.04 \pm 28.31$ & $50.8 \pm 19.9$ \\
$\mathrm{Mn}$ & $44.03 \pm 7.34$ & $48.24 \pm 6.42$ & $45.53 \pm 9.38$ & $55.6 \pm 9.8$ \\
$\mathrm{~B}$ & $\mathrm{nd}$ & $12.75 \pm 2.74$ & nd & $16.3 \pm 6.5$ \\
\hline
\end{tabular}

Statistical analysis did not detect any significant difference at $\alpha=0.05$.

Table 13. Heavy metals level $(\mathrm{mg} / \mathrm{kg})$ in corn leaves 2010 2011 (average \pm SD).

\begin{tabular}{ccccc}
\hline \multirow{2}{*}{ Element } & \multicolumn{2}{c}{ FW } & \multicolumn{2}{c}{ TWW } \\
\cline { 2 - 5 } & 2010 & 2011 & 2010 & 2011 \\
$\mathrm{Cr}$ & $2.07 \pm 0.63$ & $1.97 \pm 0.32$ & $2.07 \pm 0.41$ & $1.14 \pm 0.31$ \\
$\mathrm{Ni}$ & $1.16 \pm 0.27$ & $1.07 \pm 0.14$ & $1.77 \pm 0.68$ & $0.91 \pm 0.33$ \\
$\mathrm{Sn}$ & $53.91 \pm 3.82$ & $26.48 \pm 14.24$ & $39.55 \pm 12.25$ & $18.6 \pm 6.1$ \\
\hline
\end{tabular}

Statistical analysis detect significant difference at $\alpha=0.05$ only for $\mathrm{Cr}$ at year 2011, $\mathrm{P}$-value is $\mathrm{Cr}=0.01$.

Concentrations of $\mathrm{Zn}$ ranged between $50.8 \pm 19.9$ and $83.48 \pm 32.05 \mathrm{mg} / \mathrm{kg}$ indicating wide variations among the treatments.

Concentrations of $\mathrm{Mn}$ ranged between $44.03 \pm 7.34$ and $55.6 \pm 9.8 \mathrm{mg} / \mathrm{kg}$. This range is not as wide as in $\mathrm{Zn}$ indicating similarity among the treatments. Concentrations of B are detected only in Year 2011. Statistical analysis did not detect any significant difference at $\alpha=0.05$ level.

Concentrations of heavy metal in corn leaves are presented in Table 13. It can be seen that concentration of $\mathrm{Cr}$ ranged between $1.14 \pm 0.31$ and $2.07 \pm 0.63 \mathrm{mg} / \mathrm{kg}$ in both treatment indicating low concentrations and variations. Concentrations of $\mathrm{Ni}$ ranged between $0.91 \pm 0.33$ and $1.77 \pm 0.68 \mathrm{mg} / \mathrm{kg}$ in both treatments (FW and TWW). Concentration of Sn ranged between $18.6 \pm 6.1$ and $53.91 \pm 3.82 \mathrm{mg} / \mathrm{kg}$ indicating wide variations and high concentrations.

Concentrations of $\mathrm{Hg}, \mathrm{Pb}, \mathrm{As}$, and $\mathrm{Se}$ are under ICP detection limit. These high levels of heavy metals may be attributed to the irrigation with TWW. Our suggestion agrees with Pritchard et al. [8] who concluded that attention must be given to heavy metal uptake by plant due to irrigation with TWW.

\section{Conclusions}

The rational of this study emerges from the fact that the country suffers from arid and semi arid conditions. Accordingly, the use of treated waste water is an option to save water recourses for domestic uses. Our results demonstrated that FW and TWW have physicochemical properties that allow for a safe use. Irrigation with TWW demonstrates the effectiveness to increase the biomass of Chinese cabbage and corn. Analytical results of soil profile indicate leaching of $\mathrm{Fe}, \mathrm{Al}$, and $\mathrm{Pb}$ from the top soil and accumulation in deeper depths. This situation may pose health risk to groundwater.

Micronutrient and heavy metal contents in the plant leaves are not extremely high and can be within the range of local standards.

Although it is still too early to recommend the use of TWW as an alternative option for irrigation, the presented results are promising and encouraging. Further research work is needed before recommending TWW as an alternative source of fresh water irrigation for vegetables. The future research may include the impact of long term application of TWW on human health and environment in terms of heavy metals and pathogens.

\section{Acknowledgements}

This research was funded by DFG Grant no. GZ:MA 1830/9-2.

Special thanks to Prof Dr Bernd Marschner, Bochum University, Germny, for his suggestions during the research activity.

\section{REFERENCES}

[1] Palestinian Central Bureau of Statistics, "Palestinian National Authority, Yearly Report,” 2012.

[2] R. S. Evett Jr., S. R. Zalesny, F. N. Kandil, A. J. Stanturf and C. Soriano, "Opportunities for Woody Crop Production Using Treated Wastewater in Egypt. II. Irrigation Strategies," International Journal of Phytoremediation, Vol. 13, No. 11, 2011, pp. 122-139.

[3] G. L. Mendoza-Espinosa, A. Cabello-Pasini, V. MaciasCarranza, W. Daessle-Heuser, V. M. Orozco-Borbón and L. A. Quintanilla-Montoya, "The Effect of Reclaimed Wastewater on the Quality and Growth of Grapevines," Water Science and Technology, Vol. 57, No. 9, 2008, pp. 1445-1450. doi:10.2166/wst.2008.242

[4] G. Oron, L. Gillerman, A. Bick, Y. Manor, N. Buriakovsky and J. Hagin, "Membrane Technology for Sustainable Treated Wastewater Reuse: Agricultural, Environmental and Hydrological Considerations," Water Science and Technology, Vol. 57, No. 9, 2008, pp. 1383-1388. doi:10.2166/wst.2008.243

[5] P. K. Mosse, F. A. Patti, J. R. Smernik, W. E. Christen and R. T. Cavagnaro, "Physicochemical and Microbiological Effects of Long- and Short-Term Winery Wastewater Application to Soils," Journal of Hazardous Material, Vol. 201, No. 202, 2012, pp. 219-228. 


\section{doi:10.1016/j.jhazmat.2011.11.071}

[6] P. R. Singh, P. Singh, H. M. Ibrahim and R. Hashim, "Land Application of Sewage Sludge: Physicochemical and Microbial Response," Review of Environmental Contamination and Toxicology, Vol. 214, 2011, pp. 41-61. doi:10.1007/978-1-4614-0668-6_3

[7] E. Castro, P. M. Mañas and J. De Las Heras, "Effects of Wastewater Irrigation on Soil Properties and Turfgrass Growth," Water Science and Technology, Vol. 63, No. 8, 2011, pp. 1678-1688. doi:10.2166/wst.2011.335

[8] L. D. Pritchard, N. Penney, J. M. McLaughlin, H. Rigby and K. Schwarz, "Land Application of Sewage Sludge (Biosolids) in Australia: Risks to the Environment and Food Crops," Water Science and Technology, Vol. 62, No. 1, 2010, pp. 48-57. doi:10.2166/wst.2010.274

[9] N. O. Belyaeva, J. R. Haynes and C. E. Sturm, "Chemical, Physical and Microbial Properties and Microbial Diversity in Manufactured Soils Produced from Co-Composting Green Waste and Biosolids," Waste Management, 2012, in Press. doi:10.1016/j.wasman.2012.05.034

[10] Palestinian Central Bureau of Statistics, "Palestinian National Authority, Yearly Report," 2007.

[11] FAW, CROP WAT, VERSION 8, Food Agriculture Organization, Rome, 2007.

[12] A. D. Eaton, L. S. Clesceri and A. E. Greenberg, "Standard Methods for Wastewater Analysis," American Public Health Association, Washington DC, 20005.

[13] B. J. Jones and V. W. Case, "Sampling, Handling and Analyzing Plant Tissue Samples," In: R. L. Westerman, Ed., Soil Testing and Plant Analysis, 3rd Edition, Soil Science Society of America, Madison, 1990, pp. 389-427.

[14] D. Boruah and S. Hazarika, "Normal Water Irrigation as an Alternative to Effluent Irrigation in Improving Rice Grain Yield and Properties of a Paper Mill Effluent Affected Soil," Journal of Environmental Science and En- gineering, Vol. 52, No. 3, 2010, pp. 221-228.

[15] M. Adrover, E. Farrús, G. Moyà and J. Vadell, "Chemical Properties and Biological Activity in Soils of Mallorca Following Twenty Years of Treated Wastewater Irrigation," Journal of Environmental Management, Vol. 95, 2012, pp. 188-192. doi:10.1016/j.jenvman.2010.08.017

[16] S. G. Metson, L. R. Hale, M. D. Iwaniec, M. E. Cook, R. J. Corman, S. C. Galletti and L. D. Childers, "Phosphorus in Phoenix: A Budget and Spatial Representation of Phosphorus in an Urban Ecosystem," Ecological Applications, Vol. 22, No. 2, 2012, pp. 705-721. doi:10.1890/11-0865.1

[17] L. Ferrara, M. Iannace, M. A. Patelli and M. Arienzo, "Geochemical Survey of an Illegal Waste Disposal Site under a Waste Emergency Scenario (Northwest Naples, Italy)," Environmental Monitoring and Assessment, 2012, in Press.

[18] A. S. Hashemi, "The Investigation of Irrigation with Wastewater on Trees (Populus deltoids L.)," Toxicology and Industrial Health, 2012, in Press. doi:10.1177/0748233712442738

[19] N. Nikolic and M. Nikolic, "Gradient Analysis Reveals a Copper Paradox on Floodplain Soils under Long-Term Pollution by Mining Waste," Science of the Total Environment, Vol. 15, No. 425, 2012, pp. 146-154. doi:10.1016/j.scitotenv.2012.02.076

[20] E. B. Jones, J. R. Haynes and R. I. Phillips, “Addition of an Organic Amendment and/or Residue Mud to Bauxite Residue Sand in Order to Improve Its Properties as a Growth Medium," Journal of Environmental Management, Vol. 95, No. 1, 2012, pp. 29-38.

[21] R. S. Mousavi, M. Galavi and H. Eskandari, "Effects of Treated Municipal Wastewater on Fluctuation Trend of Leaf Area Index and Quality of Maize (Zea mays)," Water Science and Technology, Vol. 67, No. 4, 2013, pp. 797-802. doi:10.2166/wst.2012.624 